\title{
Analysis of foreign physical activity recommendations and guidelines for schools
}

\author{
Jan Pavelka*, Erik Sigmund, Zdeněk Hamřík, and Michal Kalman \\ Faculty of Physical Culture, Palacký University, Olomouc, Czech Republic
}

Copyright: (C) 2014 J. Pavelka et al. This is an open access article licensed under the Creative Commons Attribution License (http:// creativecommons.org/licenses/by/4.0/).

\begin{abstract}
Background: An adequate level of physical activity is an important part of children's lifestyle. The school environment plays a significant role in the area of interventions and strategies aiming to increase the level of physical activity in children. Objectives: The aim of this study is to analyse foreign recommendations leading to an increased level of physical activity in children and young people in Czech schools. Methods: A systematic search of studies published between 1988 and 2012 in the English language was completed in library databases Medline, Sport Discus, ProQuest, PsychInfo, ERIC, Wiley InterScience using the following keywords: physical activity, guidelines, recommendations, school and youth. The studies were then classified based on abstract and full-text analyses. Using a content analysis the expert team formulated the final recommendations to increase the level of physical activity for schools in the Czech Republic (CR). Results: Out of the total number of 91 identified foreign studies, 25 met the predetermined criteria and were used as a basis for formulating the recommendations. These foreign studies included 15 papers published in USA, two in Australia, two in Great Britain, two in Canada, one in the European Union, one in New Zealand and one international paper (an international consensus of experts from 34 countries). Based on the interpretation of the evidence, its justification and final consensus of the expert team, the basic areas for the recommendations to increase the level of physical activity in schools in the CR were identified. Conclusions: An analysis of foreign recommendations to increase the level of physical activity designed for schools and school facilities is one of the possible methods of formulating domestic recommendations. This recommendation could contribute to deeper understanding of the issue of the deteriorating lifestyle of school-aged children in the CR and reflects the efforts for improvement.
\end{abstract}

Keywords: recommendations, physical activity, school environment, children, physical education

\section{Introduction}

Overhelming evidence supports the importance of regular physical activity (PA), which has a positive effect on the health of children and young people through preventing a number of diseases, preventing overweight and obesity, decreasing high blood pressure and helping to improve mental health (Guillaume, Lapidus, Björntorp, \& Lambert, 2012; Iannotti, Kogan, Janssen, \& Boyce, 2009; Warburton, Charlesworth, Ivey, Nettlefold, \& Bredin, 2010).

PA promotion is one of the basic intervention strategies of improving the quality of life and the effort to decrease the risk and seriousness of chronic diseases. It is also an important element in increasing the effectiveness of the educational system and has a positive

\footnotetext{
* Address for correspondence: Jan Pavelka, Department of Recreology, Faculty of Physical Culture, Palacký University, tř. Míru 115, 77111 Olomouc, Czech Republic. E-mail: jan.pavelka@upol.cz
}

influence on children's study results (Bailey et al., 2009; Cradock, Melly, Allen, Morris, \& Gortmaker, 2007).

PA appears to be one of the effective tools in the fight against child overweight and obesity (Sigmund, El Ansari, \& Sigmundová, 2012; Zabinski, Saelens, Stein, Hayden-Wade, \& Wilfley, 2003). From a health perspective, lack of PA is, after smoking, high blood pressure and cholesterol, the fourth highest risk factor of non-communicable diseases (Bouchard, Blair, \& Haskell, 2012). A change in lifestyle during childhood plays a significant role in further human development in adulthood (Hills, Andersen, \& Byrne, 2011; Waters, Swinburn, Seidell, \& Uauy, 2011). Risk periods affecting the lifestyle include even early childhood (Gunter, Almstedt, \& Janz, 2012; Tremblay, Boudreau-Larivière, \& Cimon-Lambert, 2012). Therefore, this age period offers a space for targeted interventions (Harris, Kuramoto, Schulzer, \& Retallack, 2009; Pate \& O'Neill, 2009). 
A positive effect of PA on children is typically supported by targeted interventions and a change in the environment where PA takes place (De Bourdeaudhuij et al., 2010). A significant role in an effort to change the behaviour in order to increase the level of PA in children is played by the family and school (Gorman, Lackney, Rollings, \& Huang, 2012; Salmon, Timperio, Telford, Carver, \& Crawford, 2012; Sigmund \& Sigmundová, 2011). Published studies indicate that the success rate of an intervention usually depends on the cultural and social environment of a particular school, attitude of the family and motivation invoked within the society (Kitzman-Ulrich et al., 2010; Kriemler et al., 2011).

Schools offer an optimal environment for designing, implementing, and evaluating behavioural interventions to promote PA. A school not only influences children's attitude to PA but also informs of its importance in human life (Haug, Torsheim, Sallis, \& Samdal, 2010; Robertson-Wilson, Dargavel, Bryden, \& GilesCorti, 2012). One of the effective tools for increasing the level of PA in schools can be the development of evidence-based PA recommendations to promote a PA and healthy lifestyle in children (Kesäniemi, Riddoch, Reeder, Blair, \& Sørensen, 2010; Warburton, Charlesworth, Ivey, Nettlefold, \& Bredin, 2010).

The aim of this study was to, through foreign recommendations for PA promotion; formulate recommendations for school managers in elementary and secondary schools in the Czech Republic leading to an increase in the level of PA in children in both the school and out of school environment.

\section{Methods}

\section{Systematic literature search}

The criteria applied in the selection of suitable foreign literature included the following:

- target group (children and young people aged 5 to 19 years),

- type of recommendation or intervention (physical, nutrition, combined - physical + nutrition, organization),

- type of school (elementary and secondary),

- results (duration, areas of recommendation, application methods),

- year of publishing (period from 1988 to 2012).

The keywords used were physical activity, guidelines, recommendations, school and children. We searched through six electronic databases - Medline, Sport Discus, ProQuest, PsychInfo, ERIC, Wiley InterScience using the following keywords - physical activity, guidelines, recommendations, school and youth. A prerequisite for including a study in the final content analysis was its classification as a recommendation/guideline designed for children and young people without health or other restrictions aged 5 to 19 years (Figure 1).

\section{Content analysis}

The content analysis method is recommended as a simple, adaptable, systematic and objective method (Granner, Sharpe, Burroughs, Fields, \& Hallenbeck, 2010; Thomas, Nelson, Silverman, \& Silverman, 2010) for data analysis and extraction. Data extraction was performed by two researchers (JP and MK). The third reviewer's $(\mathrm{ZH})$ role was to resolve any conflicts. The data was extracted independently for each included paper using the following keywords - physical activity, guidelines, recommendations, school and youth. We used a data collection form designed before the search. We collected information on participants and study characteristics (including age and setting), curricular activities (physical education and health education), extracurricular activities (community programmes, parents' roles), policy (school strategies), school environment and teacher education. These specific areas of interest were selected in advance by the study team on the basis of accordance with previous expert papers focused on developing PA recommendations and guidelines (Silveira, Taddei, Guerra, \& Nobre, 2011; Tremblay, Boudreau-Larivière, \& Cimon-Lambert, 2012). After that we contacted independent experts to check any omissions (members of the team of authors and a foreign expert), then the recommendations to increase the level of PA in schools in the Czech Republic were developed.

\section{Results}

Out of the total number of 91 potentially suitable studies published in English between 1988 and 2012, 66 were rejected. The rejected studies did not meet the specified criteria; mostly they included different age groups of children and young people, or specific groups with diseases (Figure 1). The final analysis included a total of 25 studies. The selected foreign studies included 15 studies published in the USA, two in Great Britain, two in Australia, two in Canada, one in the European Union, one in New Zealand and one was an international study (international consensus of experts from 34 countries). Despite the fact that no language filter was applied, all detected papers were published in English. All studies were conducted in non-developing countries. The general characteristics 


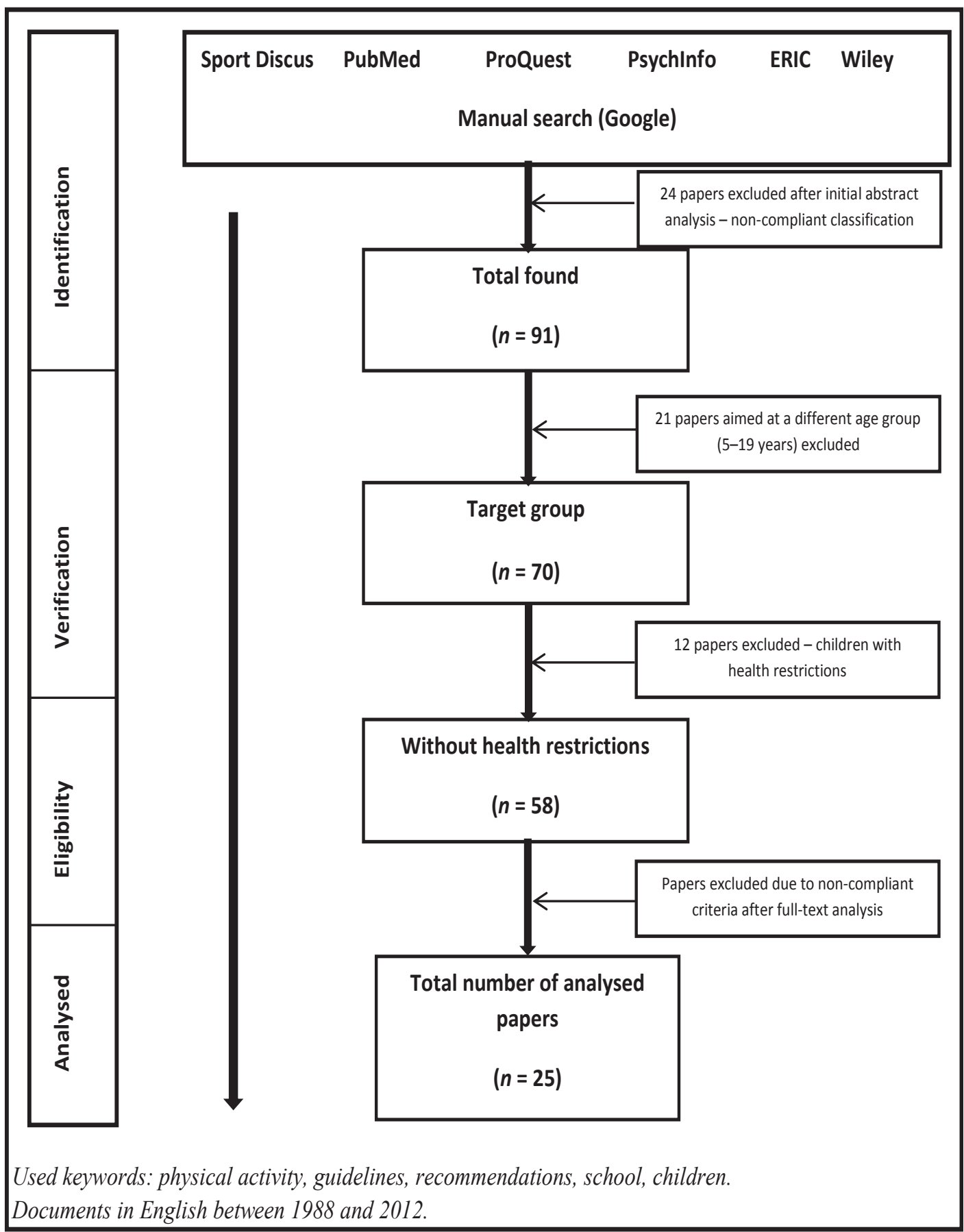

Figure 1. Paper search flowchart

of the 25 included studies were organized by their frequency and strength of effect, see Table 1.

After the content analysis (Table 2) we identified a list of most frequently repeated recommendations in terms of content and type, and grouped them into the following areas.

Strategy development - use a coordinated approach to develop, implement, and evaluate school-based PA health promoting strategy for schools and school facilities. The aim of school strategies is to provide formal as well as informal principles that schools and local organizations respect in planning, delivering and evaluating PA programmes for young people. PA school strategies should respect national as well as regional strategies and documents and recommendations. These strategies should be in the form of a written document containing information from school managers, teachers, lecturers, sports coaches, parents, 
Table 1

General characteristic of the included studies, organized by frequency and strength of effect

\begin{tabular}{lccccccc}
\hline & USA & $\begin{array}{c}\text { Great } \\
\text { Britain }\end{array}$ & Australia & Canada & $\begin{array}{c}\text { European } \\
\text { Union }\end{array}$ & $\begin{array}{c}\text { New } \\
\text { Zealand }\end{array}$ & $\begin{array}{c}\text { International } \\
\text { consensus }^{\mathrm{a}}\end{array}$ \\
\hline Number of studies & 15 & 2 & 2 & 2 & 1 & 1 & 1 \\
Strategy development & 5 & 1 & 2 & - & 1 & 1 & - \\
$\begin{array}{l}\text { School environment and } \\
\text { surroundings }\end{array}$ & 10 & - & 1 & 1 & 1 & 1 & 1 \\
Physical Education lessons & 9 & 1 & 2 & - & - & 1 & 1 \\
Health education & 4 & - & - & - & 1 & - & - \\
Extracurricular activities & 6 & - & 1 & 1 & - & 1 & 1 \\
Parents' roles & 4 & - & 1 & - & - & - & 1 \\
Teacher and staff education & 7 & - & - & - & - & 1 & - \\
Health and PA counselling & 11 & 2 & 1 & 2 & 1 & 1 & - \\
Community programmes & 5 & 1 & 1 & 1 & - & 1 & 1 \\
Evaluation & 5 & - & - & - & 1 & - & - \\
Number of strong effective & 9 & 1 & 2 & 2 & 1 & 1 & 1 \\
$\quad$ recommendations & & & & & & & \\
\hline
\end{tabular}

Note. ${ }^{a}$ International consensus of experts from 34 countries.

students and also healthcare providers, public health institutions, other schools and community workers.

School environment - establish PA-friendly and safe environment, where PA is possible without excessive restrictions. The primary objective in an effort to increase the level of PA in children and young people in schools is to make safe areas and school facilities (gyms, playing fields) available where children and pupils can perform PA. These areas should be available not only during classes but also at weekends, special days and holidays (including summer holidays). These areas and facilities should be easily available also for non-profit organizations which organize complementary activities and physically-oriented programmes.

Physical Education (PE) lessons - implement PE curricula that appeal to the natural need of children and pupils for PA and that try to create a positive attitude to PA by developing knowledge of its health benefits. Such PE lessons should help change attitudes and behaviours and support self-confidence required to adopt and maintain a physically active lifestyle. In developing the curricula, educators should take into account particularly the age and education needs of pupils, their interests and schools conditions that are often very different. Provision of complementary programmes (clubs) that motivate pupils to active participation even after classes - cooperation with non-profit organizations, cities and local authorities where the schools are located.

Health education - implement a modification of health education curricula in order to help students develop their knowledge, skills and self-confidence, and embrace behaviours and strengthen their attitudes required to adopt and maintain a physically-active lifestyle. Creating links among the educational components of health education, school PE and other subjects in the area of PA promotion - the class teacher of the class involved should be the coordinator - an example could be links among nutrition habits, which are the domain of health education and an adequate level of PA in order to maintain or reduce body weight.

Extracurricular activities - it is important to provide a sufficient offer of extracurricular activities (clubs, programmes) that meet the needs and interests of all students. Frequently offered programmes focus on competition and team sports, which can discourage less predisposed individuals in terms of physical and health fitness from participation. Undue emphasis on performance and competitiveness in childhood contributes, especially in early and late adulthood, to a decreased level of PA. Therefore, an effort should be exerted to provide a rich offer of PA programmes attractive to a wide range of pupils and students. Non-competitive activities should include walking (hiking, Nordic walking), swimming, cycling (scooters, skateboard, etc.), or newly developing PA activities - Zumba, Frisbee, etc. Highlight effective cooperation with non-profit organizations that work with young people in the area of PA; significant support (financial, organizational, material, facilities) should be provided by the municipal or local authorities; 
Table 2

Analysis of foreign recommendations to increase PA in order to promote health in children and young people - ordered by year of issue

Title of recommendation

\begin{tabular}{ll} 
Country & Source/Authors \\
\hline USA & $\begin{array}{l}\text { American College of Sports Medicine. } \\
\text { Statement for Physical Fitness in Children } \\
\text { and Youth }\end{array}$ \\
& $\begin{array}{l}\text { American College of Sports Medicine } \\
(1988)\end{array}$ \\
International & $\begin{array}{l}\text { International consensus: Physical activity } \\
\text { guidelines for adolescents }\end{array}$ \\
& Sallis \& Patrick (1994) \\
USA & $\begin{array}{l}\text { Guidelines for school and community } \\
\text { programs to promote lifelong physical } \\
\text { activity among young people }\end{array}$ \\
& $\begin{array}{l}\text { National Center for Chronic Disease } \\
\text { Prevention and Health Promotion; } \\
\text { Centers for Disease Control and Preven- } \\
\text { tion (1997) }\end{array}$
\end{tabular}

Great Britain Health Education Authority Symposium: Young and active - young people and health-enhancing physical activity evidence and implications

Biddle, Sallis, \& Cavill (1998)

USA

Healthy people 2010

Children and young people

Children and young people

Target group, age

Children and young people

Children and young people

US Department of Health and Human Services (2000)
Guidelines for after-school physical activity and intramural sport programs

NASPE, an Association of the American Alliance for Health, Physical Education, Recreation and Dance (2001)

Children and young people should accumulate 20-30 minutes of VPA each day.

Development of school-based PA and PE programmes. Encouragement and education of parents about the significance of PA.

Changed assessment of school-based PE.

All adolescents should be physically active daily, or nearly every day, as part of play games, sports, work, transportation, recreation, physical education or planned exercise in the context of family, school, and community activities.

10 areas of recommendations for schools to promote lifelong positive attitude to PA among school-aged children. The recommendations focus on the following 10 areas:

- human resources,

- strategy development,

- school curricula,

- school infrastructure,

- school and local community,

- physical education,

- extracurricular activities,

- parental involvement,

- health education,

- evaluation.

All young people should participate in PA of at least moderate intensity for one hour per day.

Young people who currently do little activity should participate in PA of at least moderate intensity for at least half an hour per day.

At least twice a week, some of these activities should help to enhance and maintain muscular strength and flexibility, and bone health.

Various types of PA are recommended.

Children and young people

Children and young people

The guidelines also recommend that should accumulate at least 60 minutes, and up to several hours, of ageappropriate PA on all, or most days of the week. Increase the proportion of adolescents who engage in vigorous PA that supports the cardiovascular system on 3 or more days in a week for 20 minutes in one session to at least $85 \%$.

To provide teachers, school activity directors and administrators and program leaders with basic information for planning and implementing complementary PA programmes for school-aged children.

All children should receive basic instruction in motor skills and sport activities through comprehensive physical education programmes.

The recommendations relate to organization and staffing, suitable complementary physical activities, appropriate equipment, health-related issues, evaluation and recommended publications for further study. 
Table 2 (continued)

\begin{tabular}{|c|c|}
\hline & Title of recommendation \\
\hline Country & Source/Authors \\
\hline \multirow[t]{2}{*}{ Canada } & $\begin{array}{l}\text { Canada's guidelines for increasing } \\
\text { physical activity in youth }\end{array}$ \\
\hline & $\begin{array}{l}\text { Canadian Society for Exercise } \\
\text { Physiology (2002) }\end{array}$ \\
\hline \multirow[t]{2}{*}{ USA } & $\begin{array}{l}\text { Position paper: The importance of physical } \\
\text { activity for children and youth }\end{array}$ \\
\hline & $\begin{array}{l}\text { Michigan Governor's Council on Physi- } \\
\text { cal Fitness, Health and Sports (2002) }\end{array}$ \\
\hline \multirow[t]{2}{*}{ USA } & $\begin{array}{l}\text { Physical activity for children: A statement } \\
\text { of guidelines }\end{array}$ \\
\hline & $\begin{array}{l}\text { Council for Physical Education for } \\
\text { Children of the NASPE, an Association } \\
\text { of the American Alliance for Health } \\
\text { Physical Education and Recreation } \\
\text { (2003) }\end{array}$ \\
\hline \multirow[t]{2}{*}{ USA } & $\begin{array}{l}\text { Kids walk to school: A guide to promote } \\
\text { walking to school }\end{array}$ \\
\hline & $\begin{array}{l}\text { USDHHS \&USDA } \\
\text { National Center for Chronic Disease } \\
\text { Prevention and Health Promotion Divi- } \\
\text { sion of Nutrition and Physical Activity } \\
\text { (2003) }\end{array}$ \\
\hline
\end{tabular}

Australia
Target group, age

Children and young people

Children and young people

Children and young people

\section{Children and young people}

$5-12$ years of age tions for 5-12 year olds

Department of Health and Ageing (2004)

Australia's physical activity recommendations for 12-18 year olds

Department of Health and Ageing (2004)

$12-18$ years of age
Areas of recommendations

Increase time spent on PA to more than 30 minutes per day in young people.

Reduce "non-active" time spent on TV, video, computer games and surfing the Internet to less than 30 minutes per day.

All schools should provide quality and sufficient PE; curriculum based on evidence based sources; should not be performance-oriented.

Schools should build opportunities for PA into the school day, including recess and lunchtime activity, etc. Children who live close to school should be encouraged to use active transportation to and from school, e.g. walking or cycling.

School recreation and exercise facilities (gyms, outside fields) should be open for use by community members during non-school hours.

Children should accumulate at least 60 minutes, and up to several hours, of age-appropriate PA on all, or most days of the week. This daily accumulation should include moderate and VPA of which the majority of is intermittent in nature.

Children should participate in several bouts of PA lasting 15 minutes or more each day.

Children should participate each day in a variety of age-appropriate physical activities designed to achieve optimum health, wellness, fitness, and performance benefits.

Periods of two hours or more of inactivity are discouraging for children, especially during the daytime hours.

Children's PA guide on their way to and from school. It should increase the number of children who use active transport on the way to and from school - walking and cycling.

Step 1 - identify interest in organized commuting to school.

Step 2 - organize group commuting, ensure safety. Step 3 - contact parents, produce a map and route of organized commuting.

Step 4 - plan schedule.

Step 5 - implement intervention.

Step 6 - assess, evaluate, plan for the future.

Children and young people need at least 60 minutes (and up to several hours) of moderate to vigorous PA every day - moderately brisk walking or cycling. Vigorous activities include organized sports such as soccer, foot tennis, dancing, jogging and swimming. Children need to have opportunities to take part in a variety of activities that are entertaining and selected according to their interests, abilities and skills. A variety of physical activities will provide children with a range of health benefits, experience and challenges.

Children and young people should not spend more than 2 hours a day using electronic media for entertainment (e.g. computer games, Internet, TV), particularly during daylight hours 
Table 2 (continued)

\begin{tabular}{|c|c|c|c|}
\hline Country & $\begin{array}{l}\text { Title of recommendation } \\
\text { Source/Authors }\end{array}$ & Target group, age & Areas of recommendations \\
\hline Great Britain & $\begin{array}{l}\text { At least five a week: Evidence of the impact } \\
\text { of physical activity and its relationship to } \\
\text { health } \\
\text { Department of Health (2004) }\end{array}$ & $\begin{array}{l}\text { Children and young } \\
\text { people }\end{array}$ & $\begin{array}{l}\text { Children and young people should reach at least } 60 \\
\text { minutes of moderate PA every day or at least twice a } \\
\text { week. This should include activities aimed at enhancing } \\
\text { health, bones, muscles and strengthening flexibility. } \\
\text { PA helps children in social interaction, feelings of } \\
\text { success, getting experience, maintaining and enhancing } \\
\text { health and development of a sustainable need to be PA. }\end{array}$ \\
\hline USA & $\begin{array}{l}\text { Evidence based physical activity for } \\
\text { school-age youth } \\
\text { Strong et al. (2005) }\end{array}$ & $\begin{array}{l}\text { Children and young } \\
\text { people }\end{array}$ & $\begin{array}{l}\text { This report includes the results of a systematic assess- } \\
\text { ment of evidence dealing with the effects of regular } \\
\text { PA on health and behaviour in school-aged children } \\
\text { in order to develop recommendations for minimum } \\
\text { amounts of PA. } \\
\text { School-aged children should daily accumulate at least } \\
60 \text { minutes of PA of MVPA that is entertaining for their } \\
\text { development }\end{array}$ \\
\hline USA & $\begin{array}{l}\text { Active healthy living: Prevention of child- } \\
\text { hood obesity through increased physical } \\
\text { activity } \\
\text { American Academy of Pediatrics (2006) }\end{array}$ & $\begin{array}{l}\text { Children and young } \\
\text { people }\end{array}$ & $\begin{array}{l}\text { Maximum of } 2 \text { hours a day of screen-based activity (TV, } \\
\text { PC). } \\
\text { Encourage children and adolescents to be physically } \\
\text { active for at least } 60 \text { minutes per day. } \\
\text { PA should be of moderate intensity and should include } \\
\text { a range of activities such as sports, recreation, active } \\
\text { transport, housework, school-based PE. }\end{array}$ \\
\hline New Zealand & $\begin{array}{l}\text { Best practice review of sport and physical } \\
\text { activity interventions for young people } \\
\text { aged 13-18 years - report to sport and } \\
\text { recreation New Zealand } \\
\text { SPARK, Auckland University of } \\
\text { Technology \& Health and Human } \\
\text { Performance Limited (2006) }\end{array}$ & $13-18$ years of age & $\begin{array}{l}\text { 1. PA recommendations and guidelines and monitoring } \\
\text { of PA in children and young people. } \\
\text { 2. Development of an organizational structure and } \\
\text { funding. } \\
\text { 3. Regular evaluation. } \\
\text { 4. Determination of priorities in the medium and long } \\
\text { term that must be measurable. } \\
\text { 5. Implementation of PA interventions. } \\
\text { 6. Designing sport and PA opportunities for children } \\
\text { and young people. }\end{array}$ \\
\hline USA & $\begin{array}{l}\text { Evidence-based practice guideline: Increas- } \\
\text { ing physical activity in schools - kindergar- } \\
\text { ten through 8th grade } \\
\text { Bagby \& Adams (2007) }\end{array}$ & $\begin{array}{l}\text { Children and young } \\
\text { people }\end{array}$ & $\begin{array}{l}\text { Focused on three methods with a strong evidence base } \\
\text { that are easy and cheap to implement and have a signifi- } \\
\text { cant influence on a positive behavioural change. } \\
\text { 1. An increase in the overall time of structured PA of } \\
\text { MVPA in PE lessons. } \\
\text { 2. An increase in the overall time of PA of MVPA dur- } \\
\text { ing recess periods. } \\
\text { 3. A significant decrease in sedentary activities (TV, } \\
\text { PC). }\end{array}$ \\
\hline $\begin{array}{l}\text { European } \\
\text { Union }\end{array}$ & $\begin{array}{l}\text { EU physical activity guidelines. Recom- } \\
\text { mended policy actions in support of } \\
\text { health-enhancing physical activity } \\
\text { EU working group: Sport \& Health } \\
(2008)\end{array}$ & $\begin{array}{l}\text { Recommendations } \\
\text { for the development } \\
\text { of policy documents }\end{array}$ & $\begin{array}{l}\text { The main purpose of this guideline and a number of } \\
\text { recommendations is to outline the priorities for the } \\
\text { development of policy documents dealing with the issue } \\
\text { of PA promotion in EU member countries. } \\
\text { The recommendations address several areas, an inter- } \\
\text { departmental approach is required - sport (organized, } \\
\text { non-organized, sport for all), health sector, education, } \\
\text { transport, working environment, senior services, } \\
\text { required evaluation. }\end{array}$ \\
\hline
\end{tabular}

(Table 2 continues) 
Table 2 (continued)

\begin{tabular}{|c|c|c|c|}
\hline & Title of recommendation & & \\
\hline Country & Source/Authors & Target group, age & Areas of recommendations \\
\hline USA & $\begin{array}{l}\text { Appropriate instructional practice } \\
\text { guidelines for elementary, middle and high } \\
\text { school physical education } \\
\text { NASPE (2009) }\end{array}$ & $\begin{array}{l}6-12,12-14,14-18 \\
\text { years of age }\end{array}$ & $\begin{array}{l}\text { School environment - safety, variety, collaboration and } \\
\text { competitiveness. } \\
\text { Development of school-based PA promotion strategies } \\
\text { - organization of in-class education, time of educa- } \\
\text { tion, use of modern technologies, qualified teachers, } \\
\text { feedback. } \\
\text { Syllabus that includes - development of skill-based } \\
\text { learning and self-experience concept, health-related } \\
\text { aspects and motivation. } \\
\text { Evaluation - assessment of selected approaches, } \\
\text { attendance evaluation, financial effectiveness, testing of } \\
\text { pupils. } \\
\text { Expertise - teacher education. }\end{array}$ \\
\hline USA & $\begin{array}{l}\text { Opportunity to learn: Guidelines for } \\
\text { elementary, middle \& high school Physical } \\
\text { Education } \\
\text { National Association for Sport and } \\
\text { Physical Education (NASPE) (2010) }\end{array}$ & $\begin{array}{l}\text { Children and young } \\
\text { people }\end{array}$ & $\begin{array}{l}\text { 1. PE teacher qualification } \\
\text { 2. Curriculum development } \\
\text { 3. Health and safety } \\
\text { 4. Class size and social climate } \\
\text { 5. School facilities and background } \\
\text { 6. Materials and equipment } \\
\text { 7. Class time allocation } \\
\text { 8. Teaching methods and procedures } \\
\text { 9. Pupil and student assessment } \\
\text { 10. Programme evaluation }\end{array}$ \\
\hline USA & $\begin{array}{l}\text { School health guidelines to promote } \\
\text { healthy eating and physical activity } \\
\text { US Department of Health and Human } \\
\text { Services, Centers for Disease Control } \\
\text { and Prevention (2011) }\end{array}$ & $6-19$ years of age & $\begin{array}{l}\text { Based on a series of previous recommendations and } \\
\text { guidelines in the area of PA and eating behaviours } \\
(1995-2009) \text {. } \\
\text { Development of a school-based health PA promoting } \\
\text { strategy, appropriate environment that is safe and moti- } \\
\text { vating for PA; long-term partnerships between schools, } \\
\text { parents and local non-profit organizations. } \\
\text { Implementation of a comprehensive PA system, in } \\
\text { which PE plays a dominant role; health education into } \\
\text { the educational system, provision of sufficient informa- } \\
\text { tion on the issue to children and pupils. } \\
\text { Employment and systematic education of school staff } \\
\text { (teaching and non-teaching) in the area of PA and } \\
\text { health }\end{array}$ \\
\hline Canada & $\begin{array}{l}\text { Canadian physical activity guidelines for } \\
\text { children 5-11 years } \\
\text { The Canadian Society for Exercise } \\
\text { Physiology (2011) }\end{array}$ & $5-11$ years of age & $\begin{array}{l}\text { School-aged children and youth should accumulate at } \\
\text { least } 60 \text { minutes of MVPA daily. } \\
\text { There are new recommendations aimed at fighting } \\
\text { sedentary behaviours. The latest change compared with } \\
\text { the previous recommendation is the absence of recom- } \\
\text { mended maximum sedentary time, which is dealt with } \\
\text { by a different document. }\end{array}$ \\
\hline USA & $\begin{array}{l}\text { Healthy people } 2020 \\
\text { U. S. Department of Health and Human } \\
\text { Services (2011) }\end{array}$ & & $\begin{array}{l}\text { Increase number of children and young people with PA- } \\
\text { oriented lifestyles; number of countries that prescribe } \\
\text { mandatory PA as a part of child care; number of } \\
\text { countries that prescribe; number of elementary and sec- } \\
\text { ondary schools that make available their sports facilities } \\
\text { (gyms, playing fields) during extracurricular time and } \\
\text { to the public; number of visits of children and young } \\
\text { people to physicians who advise on PA and healthy } \\
\text { lifestyle; proportion of short-distance active transport. } \\
\text { Decrease the number of children and young people } \\
\text { who do not observe the recommended sedentary time } \\
\text { with PC, TV and other multimedia (social networking, } \\
\text { games). }\end{array}$ \\
\hline
\end{tabular}


Parents' roles - parents should be encouraged and motivated to become a positive model and to further support their children's participation in PA programmes. Joint active leisure of parents and children induces a positive family atmosphere but also allows parents to become partners of their children in acquiring knowledge and skills, shaping of behaviour and building their attitudes. School managers should actively communicate with parents through meetings and other occasions, educational materials but also by means of developing PA programmes that are based on parents-children cooperation. Parents can also act as volunteers in organizing and leading PA clubs, or supervising in gyms or on playing fields;

Teacher and staff education - encourage further education of teachers and other staff members in the area of healthy lifestyle of children and young people with an emphasis on the significance of PA. School staff should actively motivate students and, throughout the whole course of study, provide them with knowledge and skills required for an effective promotion of pleasant lifelong PA. Use of evidence-based data on the level of PA and healthy lifestyle of children and young people that must be applied in teacher education programmes. Physical education and health education are the types of courses in which children and adolescents can be motivated to PA through practical demonstrations and performance of PA.

Health and PA counselling - each school should have a PA and health specialist who should be capable of providing well-founded information about suitable PA for various age groups of children and pupils, and monitoring the implementation of school programmes aimed at PA promotion and healthy lifestyle. Important is to minimise the absence of pupils in PE lessons.

Community programmes - each school should closely cooperate with local organizations on the development of PA programmes designed not only for young people but also local citizens, provision of facilities (gym, outdoor playing field, swimming pool, athletic stadium) for performing PA. Extracurricular PA constitutes a significant part of all-day PA of children and adolescents. Therefore, PA promotion must also include a more focused and closer cooperation with non-profit organizations, citizens' associations, interest groups and sports organizations in developing complementary extracurricular PA programmes. Financing of extracurricular programmes must be supported by local governments in cities and municipalities.

Evaluation - conduct regular evaluation of PA promotion activities and programmes in a school environment. The evaluation should focus primarily on the processes in short-term as well as long-term perspective in terms of both effectiveness of the developed strategies and intervention programmes and a change in and adoption of behaviours of pupils and students in order to embrace and maintain a physically active lifestyle. The most frequently used evaluation techniques for determining the level of PA include especially questionnaires and record sheets, often combined with pedometers and accelerometers or the International Physical Activity Questionnaire (IPAQ).

\section{Discussion}

The aim of the study is, through an analysis of foreign recommendations, to formulate recommendations for elementary and secondary school managers in the Czech Republic leading to an increase in the level of PA in pupils in both school and out of school environments.

Increasing the level of PA in school-aged children as well as preventing a further increase in overweight and obesity requires cooperation between parents, teachers, schools and school facility managers and children. In spite of the fact that partial physical interventions are effective in dealing with an insufficient level of PA and overweight and obesity reduction in children (Jansen et al., 2011; Sigmund, El Ansari, \& Sigmundová, 2012), a more systematic and general approach must be implemented (Story, Kaphingst, Robinson-O'Brien, \& Glanz, 2008). Regarding the fact that the school environment presents one of the key locations for various interventions, particularly of a physical nature, this setting must be focused on (Jansen et al., 2011; Khambalia, Dickinson, Hardy, Gill, \& Baur, 2012; Lavelle, Mackay, \& Pell, 2012; Waters, de Silva-Sanigorski, et al., 2011).

A series of recommendations based on the presented analysis of foreign studies (Table 2) are designed to promote PA in schoolchildren and young people aged 5 to 19 by increasing its level. The defined recommendations are intended especially for schools and school facility managers. We based the development of this guide on 25 foreign papers supported by research results in the area of PA. A significant part of the overall concept leading to a sustainable improvement of individual determinants of schoolchildren's healthy lifestyle is the quality of school environment and the promotion of teacher education as well as other staff ( $60 \%$ of all recommendations is focused on the impact of school environment and $32 \%$ on teacher education). School employees (teaching as well as non-teaching) should actively motivate students and provide them with sufficient knowledge and skills required for an effective promotion of pleasant lifelong PA. These recommendations are in accordance with foreign 
recommendations (Baranowski et al., 1997; Michigan Department of Community Health, 2002; NASPE, 2001, 2009a, 2009b, 2009c, 2010; USDHHS \& USDA, 2011). The role of the teacher and educator is perceived as one of the most significant areas in the process of increasing the level of PA (Cothran, Kulinna, \& Garn, 2010; McDavid, Cox, \& Amorose, 2012). One of the key elements to achieve this is a systematic process of teacher education in the areas of active lifestyle and PA (Schwarz, 2011; Tessier, Sarrazin, \& Ntoumanis, 2010).

The performed analyses also show that one of the possibilities of systematically addressing the insufficient level of PA in schools may be the development of school-based strategies that provide formal and informal principles governing school-based planning, implementation and assessment of PA promotion programmes (40\% of recommendations) (Kropski, Keckley, \& Jensen, 2012) and at the same time should comply with applicable national and regional strategies, documents and recommendations (Simovska, Dadaczynski, \& Woynarowska, 2012). These strategies should be in the form of a written document that contains information provided by school managers, teachers, lecturers, sports coaches, parents, students, but also health care providers, public health, other schools and community workers (ACSM, 1988; Baranowski et al., 1997; EC, 2008; Kolt et al., 2006; NASPE, 2009a, 2009b, 2009c; USDHHS \& USDA, 2003, 2011). The development of school strategies and action plans to promote and increase the level of PA in children and young people is considered one of the basic elements in an effective approach to address the issue (Brennan, Castro, Brownson, Claus, \& Orleans, 2011; Evenson, Ballard, Lee, \& Ammerman, 2009; Harris, Kuramoto, Schulzer, \& Retallack, 2009). In the Czech Republic, however, such strategies and recommendations do not exist at the moment or are not comprehensive (Kalman, Hamř́k, \& Pavelka, 2009).

The school environment is suitable for the implementation of PA programmes (Dobbins, De Corby, Robeson, Husson, \& Tirilis, 2009; Teufel-Shone, Fitzgerald, Teufel-Shone, \& Gamber, 2009) through which PE (56\% of recommendations) and health education curricula (20\% of recommendations) can be implemented that appeal to the natural need for PA in children and young people and become a basis for an active lifelong learning (Donnelly et al., 2009). A significant element is also the blending of "school life" and "out of school life" and active development of the knowledge of PA and its significance for health, helping to change attitudes and behaviours and support self-confidence required for adopting and maintaining a physically active lifestyle (ACSM, 1988; Bagby
\& Adams, 2007; Baranowski et al., 1997; Michigan Department of Community Health, 2002; NASPE, 2009a, 2009b, 2009c, 2010; Sallis \& Patrick, 1994; USDHHS \& USDA, 2011).

PA, which is an inseparable and cross-section part of school curricula also in the Czech Republic (Sigmund, Sigmundová, Frömel, \& Vašíčková, 2010), can result in an increase in the natural need for PA and improved study results in schoolchildren (Donnelly et al., 2009; Kibbe et al., 2011). An important educative aspect that can have a positive influence on the level of PA in children includes school facilities and equipment, particularly the learning environment and material equipment that should be appropriate in terms of purpose, hygiene and aesthetics (Gorman, Lackney, Rollings, \& Huang, 2012; Gronberg, Jansen, \& Taylor, 2011). The provision of a safe and appropriate environment for performing PA can be achieved by making school facilities accessible (gym, outdoor field), making sports facilities available outside school lessons (weekends, holidays), promoting active transport (bicycle stands, lockers), during school lessons and breaks - providing opportunities to stretch on the carpet, do exercise, relax, PA should not be used as a form of punishment (ACSM, 1988; Baranowski et al., 1997; Department of Health and Ageing, 2004a, 2004b; Michigan Department of Community Health, 2002; NASPE, 2001, 2010; USDHHS, 2011; USDHHS \& USDA, 2011). The results of the foreign studies indicate $(60 \%$ of analysed recommendations) that the quality of the environment and school surroundings plays an important role in promoting PA in school-aged children (Colabianchi, Kinsella, Coulton, \& Moore, 2009; Haug, Torsheim, Sallis, \& Samdal, 2010; Lanningham-Foster et al., 2008). Based on the comparison with the results of studies dealing with school conditions and background suitable for PA promotion in the Czech Republic, it is clear that this area must be addressed in a systematic way. This primarily includes insufficient material equipment, unsuitable conditions for the promotion of active transport and related safety around schools (Pavelka, Sigmundová, Hamrík, \& Kalman, 2012).

In an effort to increase the level of PA in schools, not only students and teachers must be involved. At least $24 \%$ of analysed recommendations emphasize also parents' roles. In this context, parents' participation in extracurricular activities of PA nature is of utmost importance (Zecevic, Tremblay, Lovsin, \& Michel, 2010). Parents should also be involved in the process of increasing the overall level of PA in children (Kitzman-Ulrich et al., 2010). An important part of the process is an effort to encourage and motivate them to become models for their children and to promote their children's participation in additional activities of 
a PA nature (ACSM, 1988; Baranowski et al., 1997; NASPE, 2010; USDHHS \& USDA, 2011). Irrespective of gender and age, the correlations between parents' and their children's PA are positive, they are primarily found in the duration of everyday walking, followed by overall weekly PA and moderate-to-vigorous PA. It can be concluded that "more active parents, both fathers and mothers, bring up more physically active children" (Sigmund, Sigmundová, Frömel, \& Vašíčková, 2010).

\section{Strengths and limitations}

An important strength is that we collected relevantly developed, research-based recommendations to identify any gaps in existing knowledge and to establish the priorities for future research. The research recommendations were formulated by experts for future iterative reviews and modifications. Our study also has several limitations. Firstly, because we did not include unpublished studies and studies that were published in a different language than English, and because we did not perform extensive cross-referencing of the reference lists in the papers that were retrieved from electronic databases, several relevant papers may have been excluded. Secondly, the review was limited to 10 main outcomes and did not include several other outcomes that may be relevant for children and youth (risky and aggressive behaviours and measures of mental health and well-being). Generally, these limitations may have biased the results and recommendations that were developed.

\section{Conclusions and recommendations}

The presented recommendations are intended for schools and school facility managers. They should facilitate the formulation and application of their own PA recommendations in schools and school facilities towards a sustainable increase in the level of PA in school-aged children. The proposed recommendations reflect the need for a systematic approach to the unsatisfactory lifestyle of school-aged children in the Czech Republic. The formulated recommendations encourage further scientific discussions and constructive comments in order to develop recommendations acceptable on a national scale.

\section{Acknowledgment}

This study was supported by the ECOP project "Strengthening the scientific potential of research teams in promoting physical activity at Palacký University" reg. no. CZ.1.07/2.3.00/20.0171 and research grant of Czech Science Foundation "Trends in overweight and obesity, physical activity and sedentary behaviour among Czech schoolchildren: HBSC study between 2002 and 2014”, reg. no. GA14-02804S.

\section{References}

ACSM. (1988). American College of Sports Medicine opinion statement on physical fitness in children and youth. Medicine \& Science in Sports \& Exercise, 20, 422-423.

Bagby, K., \& Adams, S. (2007). Evidence-based practice guideline: Increasing physical activity in schools - kindergarten through 8th grade. The Journal of School Nursing, 23, 137-143.

Bailey, R., Armour, K., Kirk, D., Jess, M., Pickup, I., Sandford, R., \& Education, B. (2009). The educational benefits claimed for physical education and school sport: An academic review. Research Papers in Education, 24, 1-27.

Baranowski, T., Bar-Or, O., Blair, S., Corbin, C., Dowda, M., Freedson, R., ... Saunders, R. (1997). Guidelines for school and community programs to promote lifelong physical activity among young people. Morbidity and Mortality Weekly Report, 50, 1-36.

Biddle, S. J. H., Sallis, J. F., \& Cavill, N. (1998). Young and active - young people and health-enhancing physical activity - evidence and implications. London: Health Education Authority.

Bouchard, C., Blair, S. N., \& Haskell, W. L. (2012). Physical activity and health. Champaign, IL: Human Kinetics.

Brennan, L., Castro, S., Brownson, R. C., Claus, J., \& Orleans, C. T. (2011). Accelerating evidence reviews and broadening evidence standards to identify effective, promising, and emerging policy and environmental strategies for prevention of childhood obesity. Annual Review of Public Health, 32, 199-223.

Colabianchi, N., Kinsella, A. E., Coulton, C. J., \& Moore, S. M. (2009). Utilization and physical activity levels at renovated and unrenovated school playgrounds. Preventive Medicine, 48, 140-143. doi:http://dx.doi.org/10.1016/j. ypmed.2008.11.005

Corbin, C., \& Pangrazi, R. (2003). Physical activity for children: A statement of guidelines. Reston, VA: NASPE Publications.

COSMF. (2006). Active healthy living: prevention of childhood obesity through increased physical activity. Pediatrics, 117, 1834-1842. doi:10.1542/peds.2006-0472

Cothran, D. J., Kulinna, P. H., \& Garn, A. C. (2010). Classroom teachers and physical activity integration. Teaching and Teacher Education, 26, 1381-1388. doi http://dx.doi. org/10.1016/j.tate.2010.04.003

Cradock, A., Melly, S., Allen, J., Morris, J., \& Gortmaker, S. (2007). Characteristics of school campuses and physical activity among youth. American Journal of Preventive Medicine, 33, 106-113. doi:10.1016/j.amepre.2007.04.009.

CSEP. (2002). Canada's guidelines for increasing physical activity in youth. Otawa: Public Works and Government Services Canada.

De Bourdeaudhuij, I., Van Cauwenberghe, E., Spittaels, H., Oppert, J. M., Rostami, C., Brug, J., ... Maes, L. (2010). School-based interventions promoting both physical 
activity and healthy eating in Europe: A systematic review within the HOPE project. Obesity Reviews, 12, 205-216.

Department of Health and Ageing, Australia. (2004a). Australia's physical activity recommendations for 5-12 year olds. Canberra: Author.

Department of Health and Ageing, Australia. (2004b). Australia's physical activity recommendations for 12-18 year olds. Canberra: Author.

Department of Health, U. K. (2004). At least five a week: Evidence on the impact of physical activity and its relationship to health. London: Author.

Dobbins, M., De Corby, K., Robeson, P., Husson, H., \& Tirilis, D. (2009). School-based physical activity programs for promoting physical activity and fitness in children and adolescents aged 6-18. Cochrane Database of Systematic Reviews, 1, CD007651. doi:10.1002/14651858. CD007651

Donnelly, J. E., Greene, J. L., Gibson, C. A., Smith, B. K., Washburn, R. A., Sullivan, D. K., ... Williams, S. L. (2009). Physical Activity Across the Curriculum (PAAC): A randomized controlled trial to promote physical activity and diminish overweight and obesity in elementary school children. Preventive Medicine, 49, 336-341. doi:10.1016/j. ypmed.2009.07.022

EC. (2008). EU physical activity guidelines. Recommended policy actions in support of health-enhancing physical activity. Brussels: Author.

Evenson, K. R., Ballard, K., Lee, G., \& Ammerman, A. (2009). Implementation of a school-based state policy to increase physical activity. Journal of School Health, 79, 231-238. doi:10.1111/j.1746-1561.2009.00403.x

Gorman, N., Lackney, J. A., Rollings, K., \& Huang, T. T. K. (2012). Designer schools: The role of school space and architecture in obesity prevention. Obesity, 15, 2521-2530.

Granner, M. L., Sharpe, P. A., Burroughs, E. L., Fields, R., \& Hallenbeck, J. (2010). Newspaper content analysis in evaluation of a community-based participatory project to increase physical activity. Health Education Research, 25, 656-667.

Gronberg, T. J., Jansen, D. W., \& Taylor, L. L. (2011). The impact of facilities on the cost of education. National Tax Journal, 64, 193-218.

Guillaume, M., Lapidus, L., Björntorp, P., \& Lambert, A. (2012). Physical activity, obesity, and cardiovascular risk factors in children. The Belgian Luxembourg child study II. Obesity Research, 5, 549-556.

Gunter, K. B., Almstedt, H. C., \& Janz, K. F. (2012). Physical activity in childhood may be the key to optimizing lifespan skeletal health. Exercise and Sport Sciences Reviews, 40, 13-21. doi:10.1097/JES.0b013e318236e5ee

Harris, K. C., Kuramoto, L. K., Schulzer, M., \& Retallack, J. E. (2009). Effect of school-based physical activity interventions on body mass index in children: A meta-analysis. Canadian Medical Association Journal, 180, 719-726. doi:10.1503/cmaj.080966

Haug, E., Torsheim, T., Sallis, J. F., \& Samdal, O. (2010). The characteristics of the outdoor school environment associated with physical activity. Health Education Research, 25, 248-256. doi:10.1093/her/cyn050

Hills, A. P., Andersen, L. B., \& Byrne, N. M. (2011). Physical activity and obesity in children. British Journal of Sports Medicine, 45, 866-870.

Iannotti, R. J., Kogan, M. D., Janssen, I., \& Boyce, W. F. (2009). Patterns of adolescent physical activity, screenbased media use, and positive and negative health indicators in the US and Canada. Journal of Adolescent Health, 44, 493-499. doi:10.1016/j.jadohealth.2008.10.142

Jansen, W., Borsboom, G., Meima, A., Zwanenburg, E. J.-V., Mackenbach, J. P., Raat, H., \& Brug, J. (2011). Effectiveness of a primary school-based intervention to reduce overweight. International Journal of Pediatric Obesity, 6, 70-77. doi:10.3109/17477166.2011.575151

Kalman, M., Hamřík, Z., \& Pavelka, J. (2009). Podpora pohybové aktivity pro odbornou veřejnost [Physical activity promotion for professionals]. Olomouc: ORE institut, o. p. s.

Kesäniemi, A., Riddoch, C. J., Reeder, B., Blair, S. N., \& Sørensen, T. I. (2010). Advancing the future of physical activity guidelines in Canada: An independent expert panel interpretation of the evidence. International Journal of Behavioral Nutrition and Physical Activity, 41, 1-14. doi:10.1186/1479-5868-7-41

Khambalia, A. Z., Dickinson, S., Hardy, L. L., Gill, T., \& Baur, L. A. (2012). A synthesis of existing systematic reviews and meta-analyses of school-based behavioural interventions for controlling and preventing obesity. Obesity Reviews, 13, 214-233. doi:10.1111/j.1467-789X.2011.00947.x

Kibbe, D. L., Hackett, J., Hurley, M., McFarland, A., Schubert, K. G., Schultz, A., \& Harris, S. (2011). Ten years of TAKE 10 ! $($ Integrating physical activity with academic concepts in elementary school classrooms. Preventive Medicine, 52(Suppl.), 43-50. doi:10.1016/j.ypmed.2011.01.025

Kitzman-Ulrich, H., Wilson, D. K., St. George, S. M., Lawman, H., Segal, M., \& Fairchild, A. (2010). The integration of a family systems approach for understanding youth obesity, physical activity, and dietary programs. Clinical Child and Family Psychology Review, 13, 231-253.

Kolt, G., Schofield, G., Schofield, L., McLachlan, C., Svendsen, C., \& Mackay, L. (2006). Best practice review of sport and physical activity interventions for young people aged 13-18 years: Report to sport and recreation New Zealand volume. Auckland: Auckland University of Technology.

Kriemler, S., Meyer, U., Martin, E., van Sluijs, E. M. F., Andersen, L., \& Martin, B. (2011). Effect of school-based interventions on physical activity and fitness in children and adolescents: A review of reviews and systematic update. British Journal of Sports Medicine, 45, 923-930. doi:10.1136/bjsports-2011-090186

Kropski, J. A., Keckley, P. H., \& Jensen, G. L. (2012). Schoolbased obesity prevention programs: An evidence-based review. Obesity, 16, 1009-1018. doi:10.1038/oby.2008.29

Lanningham-Foster, L., Foster, R. C., McCrady, S. K., Manohar, C. U., Jensen, T. B., Mitre, N.G., ... Levine, J. A. (2008). Changing the school environment to increase physical activity in children. Obesity, 16, 1849-1853. doi:10.1038/oby.2008.282

Lavelle, H. V., Mackay, D. F., \& Pell, J. P. (2012). Systematic review and meta-analysis of school-based interventions to reduce body mass index. Journal of Public Health, 34, 360-369. doi:10.1093/pubmed/fdr116

McDavid, L., Cox, A. E., \& Amorose, A. J. (2012). The relative roles of physical education teachers and parents in adolescents' leisure-time physical activity motivation and behavior. Psychology of Sport and Exercise, 13, 99-107. doi:10.1016/j.psychsport.2011.10.003

Michigan Department of Community Health. (2002). The importance of physical activity for children and youth. Lancing: The Governor's Council on Physical Fitness, Health and Sports. 
NASPE. (2001). Quidelines for after-school physical activity and intramural sport programs. Reston, VA: Author.

NASPE. (2009a). Appropriate instructional practice guidelines for elementary school physical education. Reston, VA: Author.

NASPE. (2009b). Appropriate instructional practice guidelines for high school physical education. Reston, VA: Author.

NASPE. (2009c). Appropriate instructional practice guidelines for middle school physical education. Reston, VA: Author.

NASPE. (2010). Opportunity to learn guidelines for elementary, middle \& high school physical education. Reston, VA: Author .

Pate, R. R., \& O’Neill, J. (2009). After-school interventions to increase physical activity among youth. British Journal of Sports Medicine, 43, 14-18. doi:10.1136/bjsm.2008.055517

Pavelka, J., Sigmundová, D., Hamř́k, Z., \& Kalman, M. (2012). Active transport among Czech school-aged children. Acta Universitatis Palackianae Olomucensis. Gymnica, 41(3), 17-26.

Robertson-Wilson, J. E., Dargavel, M. D., Bryden, P. J., \& Giles-Corti, B. (2012). Physical activity policies and legislation in schools: A systematic review. American Journal of Preventive Medicine, 43, 643-649. doi:10.1016/j. amepre.2012.08.022

Sallis, J., \& Patrick, K. (1994). Physical activity guidelines for adolescents: Consensus statement. Pediatric Exercise Science, 6, 302.

Salmon, J., Timperio, A., Telford, A., Carver, A., \& Crawford, D. (2012). Association of family environment with children's television viewing and with low level of physical activity. Obesity Research, 13, 1939-1951. doi:10.1038/ oby.2005.239

Schwarz, R. (2011). The importance of physical education teachers in Germany: Theoretical and educational system considerations of the concept of profession. Baltic Journal of Health and Physical Activity, 3, 208-217.

Sigmund, E., El Ansari, W., \& Sigmundová, D. (2012). Does school-based physical activity decrease overweight and obesity in children aged 6-9 years? A two year non-randomized longitudinal intervention study in the Czech Republic. BMC Public Health, 12, 1-13. doi:10.1186/1471-2458-12-570

Sigmund, E., \& Sigmundová, D. (2011). Pohybová aktivita pro podporu zdraví détí a mládeže [Physical activity for health support of children and youth]. Olomouc: Univerzita Palackého.

Sigmund, E., Sigmundová, D., Frömel, K., \& Vašíčková, J. (2010). Preferred contents in physical education lessons positively evaluated means of higher intensity of physical activity by girls. Acta Universitatis Palackianae Olomucensis. Gymnica, 40(2), 7-16.

Silveira, J. A. C., Taddei, J. A. A. C., Guerra, P. H., \& Nobre, M. R. C. (2011). Effectiveness of school-based nutrition education interventions to prevent and reduce excessive weight gain in children and adolescents: A systematic review. Jornal de Pediatria, 87, 382-392. doi:10.2223/ jped. 2123

Simovska, V., Dadaczynski, K., \& Woynarowska, B. (2012). Healthy eating and physical activity in schools in Europe: A toolkit for policy development and its implementation. Health Education, 112, 513-524. doi:10.1108/09654281211275863

Story, M., Kaphingst, K. M., Robinson-O’Brien, R., \& Glanz, K. (2008). Creating healthy food and eating environments:
Policy and environmental approaches. Annual Review of Public Health, 29, 253-272.

Strong, W., Malina, R., Blimkie, C., Daniels, S., Dishman, R., Gutin, B., ... Pivarnik, J. (2005). Evidence based physical activity for school-age youth. The Journal of Pediatrics, 146, 732-737. doi:10.1016/j.jpeds.2005.01.055

Tessier, D., Sarrazin, P., \& Ntoumanis, N. (2010). The effect of an intervention to improve newly qualified teachers' interpersonal style, students motivation and psychological need satisfaction in sport-based physical education. Contemporary Educational Psychology, 35, 242-253. doi: 0.1016/j.cedpsych.2010.05.005

Teufel-Shone, N. I., Fitzgerald, C., Teufel-Shone, L., \& Gamber, M. (2009). Systematic review of physical activity interventions implemented with American Indian and Alaska native populations in the United States and Canada. American Journal of Health Promotion, 23, S8-S32. doi:10.4278/ ajhp.07053151

Thomas, J. R., Nelson, J. K., Silverman, S., \& Silverman, S. J. (2010). Research methods in physical activity (6th ed.). Champaign, IL: Human Kinetics.

Tremblay, L., Boudreau-Larivière, C., \& Cimon-Lambert, K. (2012). Promoting physical activity in preschoolers: A review of the guidelines, barriers, and facilitators for implementation of policies and practices. Canadian Psychology/Psychologie Canadienne, 53, 280-290. doi:10.1037/ a0030210

Tremblay, M., Warburton, D., Janssen, I., Paterson, D., Latimer, A., Rhodes, R., ... Zehr, L. (2011). New Canadian physical activity guidelines. Applied Physiology Nutrition and Metabolism, 36, 36-46. doi:10.1139/H11-009

USDHHS. (2000). Healthy people 2010: Understanding and improving health. Washington, DC: U.S. Government Printing Office.

USDHHS. (2011). Healthy people 2020. Washington, DC: U. S. Department of Health and Human Services.

USDHHS, \& USDA. (2003). Kids walk to school: A guide to promote walking to school. Atlanta, GA: U. S. Department of Health and Human Services.

USDHHS, \& USDA. (2011). School health guidelines to promote healthy eating and physical activity. Atlanta, GA: U. S. Department of Health and Human Services.

Warburton, D., Charlesworth, S., Ivey, A., Nettlefold, L., \& Bredin, S. S. (2010). A systematic review of the evidence for Canada's physical activity guidelines for adults. International Journal of Behavioral Nutrition and Physical Activity, 7(39), 1-220. doi:10.1186/1479-5868-7-39

Waters, E., de Silva-Sanigorski, A., Hall, B. J., Brown, T., Campbell, K. J., Gao, Y., ... Summerbell, C. D. (2011). Interventions for preventing obesity in children. Cochrane Database of Systematic Reviews, 12, 1-224. doi:10.1002/14651858. CD001871.pub3

Waters, E., Swinburn, B., Seidell, J., \& Uauy, R. (Eds.). (2011). Preventing childhood obesity: Evidence policy and practice (vol. 62). Chichester: Wiley-Blackwell.

Zabinski, M. F., Saelens, B. E., Stein, R. I., Hayden-Wade, H. A., \& Wilfley, D. E. (2003). Overweight children's barriers to and support for physical activity. Obesity Research, 11, 238-246. doi:10.1038/oby.2003.37

Zecevic, C. A., Tremblay, L., Lovsin, T., \& Michel, L. (2010). Parental influence on young children's physical activity. International Journal of Pediatrics, 2010, 1-9. doi: $10.1155 / 2010 / 468526$. 